\title{
Vestígios memoriais: fecundando as literaturas das Américas
}

\author{
Zilá Bernd $^{1}$
}

Resumé: L'article propose une réflexion théorique sur le concept de traces, en évoquant ses origines ainsi que les principaux auteurs qui l'ont utilisé, en introduisant des variantes terminologiques comme "rastros", "ruines", "résidus", etc. L'article souligne l'importance du concept dans la construction des littératures des Amériques contemporaines et présente un exemple de roman de la litérature brésilienne, construit à partir des résidus mémoriaux: Breviário das terras do Brasil, de Luiz Antonio de Assis Brasil (1997).

Mots-clés: esthétique des traces, residus mémoriaux, littérature brésilienne, mémoire collective

Resumo: O artigo pretende se deter em uma reflexão teórica sobre os vestígios (traces), evocando as origens do conceito bem como os principais autores que o utilizaram, introduzindo variantes terminológicas como "rastros", "ruínas", "resíduos", etc. Leva-se em conta a importância desse conceito para a leitura das literaturas das Américas na contemporaneidade e apresenta-se um exemplo de romance da literatura brasileira, construído a partir de resíduos memoriais: Breviário das terras do Brasil, de Luiz Antonio de Assis Brasil (1997).

Palavras-chaves: estética dos vestígios, rastros, resíduos memoriais, literatura brasileira, memória coletiva

La littérature ne récrit pas l'histoire, elle invente du temps que l'histoire n'a pas "retenu": un temps anamnésique plutôt que mémoriel, un temps d'oubli que seule la parole peut remonter jusqu'à la source. L'écriture poétique ou romanesque relève en effet, dans ses reliefs les plus saillants, ses excroissances les plus prégnantes, de qui tombe ou est tombé dans l'oubli le plus profond, dans les creux de l'histoire, les anfractuosités de la mémoire, ses failles, ses interstices, que la fiction seule peut pénétrer, puis explorer . ${ }^{2}$

\footnotetext{
1 Zilá Bernd é professora colaboradora convidada do PPG-Letras/UFRGS, e professora do mestrado em Memória Social e Bens Culturais do UNILASALLE/Canoas. É bolsista PQ do CNPq. Atua nas áreas de literaturas da francofonia nas Américas, brasileira, afro-brasileira e comparada. zilab@uol.com.br 2 (Ouellet, 2008, p. 13).
} 


\section{A ficção como lugar privilegiado de memória}

Partindo dos pressupostos teóricos, que alicerçam a estética dos vestígios, consideramos a importância de explorar este tempo que a história não foi capaz de "reter", para perscrutar em romances e em textos poéticos americanos, essas "falhas" e "interstícios" de que nos fala Pierre Ouellet. Ele próprio ficcionista e poeta além de teórico da literatura, sustenta que só a literatura pode penetrar nas falhas e desvãos da história e da memória, tentando proceder à anamnese para remontar à fonte do vivido, reinventando-o, através da ficção na tentativa de colmatar os não-ditos da história.

Se, por um lado, interessa para a estética dos vestígios flagrar nos textos ficcionais esse "tempo do esquecimento", que emerge através da palavra poética, interessa perceber também o que a literatura, por sua vez, tenta ocultar em determinados períodos e apontar como certos temas-tabu re-emergem em outros períodos da história literária.

Ainda conforme o autor quebequense, não são as ideologias, nem a opinião pública ou o discurso midiático que desvelam o "esprit du temps", mas é a palavra poética que consegue enunciar com maior pertinência a "socialidade estésica" ou a sensibilidade compartilhada, reveladora do sentido "da vida sensível de uma coletividade em uma determinada etapa de sua evolução" (2008, p. 153).

Partimos então do princípio de que a investigação sobre a ficção romanesca do final do século XX e princípios dos XXI é o lugar privilegiado de memória coletiva, permitindo a decodificação das escolhas que as comunidades novas das Américas fizeram e fazem em relação a suas ancestralidades. Além da escolha e da adoção da memória longa, Gérard Bouchard menciona a ocorrência de "nós de memória" que consistem na recusa ou incapacidade de rememorar "memórias vergonhosas", levando à criação de mitologias de substituição. Pretende-se mostrar a importância desse viés investigativo aplicado sobretudo às literaturas das Américas, sublinhando as estratégias utilizadas pela ficção para camuflar o "mal-estar da origem" que são, na pós-modernidade, convertidas em seu avesso, notandose a necessidade imperiosa de romper pactos de silêncio, de reconhecer a impureza das origens e libertar a memória vergonhosa, desfazendo os nós de memória acima citados (Bouchard, 2009). O autor alerta que ficar atento aos jogos e aos nós de memória torna-se, em determinados casos, mais importante do que analisar os "lugares de memória" (Pierre Nora), já que os casos de bloqueio e de amnésia geram situações de ambivalência que podem ser reveladores do identitário em determinados estados de sociedade.

$\mathrm{O}$ ato de desfazer os nós leva os escritores a realizar o trabalho da (an)amnésia que contém, ao mesmo tempo, "a ideia de amnésia (perda da memória) e anamnésia (recuperação, restabelecimento da memória)" (MOSER, 2009, p.17). O autor refere que memória e esquecimento não constituem uma oposição binária, mas que o esquecimento se constitui como uma necessidade operacional no jogo dialético memória/esquecimento. Assim, salienta o fato de que as transferências culturais têm uma "necessidade sistêmica de esquecimento", apresentando o seguinte exemplo: "para que a flor-de-lis dos Bourbon possa se tornar um símbolo identitário na bandeira quebequense é necessário esquecer o que ela era antes, e que ainda o é - um símbolo da monarquia francesa" (p.18). Nesse sentido, Walter Moser, que vem estudando há muitos anos as mobilidades e transferências culturais, sublinha que em toda transferência cultural há um momento inicial de transporte de materiais de um sistema doador a um sistema receptor; depois dá-se o deslocamento e a inserção deste material na cultura do novo sistema. Nesse processo é necessário que 
a identidade original do material seja apagada: "quanto mais a identidade original do material é esquecida no processo, mais o material estará disponível para uma reinserção bem-sucedida no novo sistema" (p.19).

Na medida em que as culturas do Novo Mundo se constroem e se desconstroem com base em incessantes processos de transculturação, a questão do esquecimento envolvido nestes processos é extremamente pertinente ao estudo que nos propomos desenvolver no âmbito do presente artigo.

\section{Desvendando o conceito de trace}

$\mathrm{O}$ artigo visa a analisar as estratégias utilizadas por autores das literaturas das Américas de construir uma memória longa (G. Bouchard) ou memória de longa duração (F. Braudel) com base na recuperação de vestígios (traces) oriundos de memórias múltiplas em circulação no contexto crioulizado das Américas. Nesse sentido, no entrelugar entre memória, esquecimento e silêncio, criam-se estéticas feitas de vestígios culturais os mais diversos que pretende-se mapear, analisar e classificar de acordo com as diferentes estratégias que determinam, de um lado, o trabalho, o dever e os abusos de memória, e, de outro, o esquecimento, o não-dito, o silêncio e os mecanismos ativadores de memórias reinventadas.

Para essa proposta de leitura, torna-se fundamental uma breve revisão do conceito de trace. Assim, apresentamos, de forma resumida, os pressupostos teóricos de Jacques Derrida, retomados por Édouard Glissant, além de mencionar os estudos de Carlo Ginzburg sobre o conceito de "rastros" e de Paul Ricoeur, sobre as "marcas". Como sabemos, a noção de trace pode ser entendida como a ausência de uma presença: seria o simulacro de uma presença que se desloca. Em Le monolinguisme de l'autre, Derrida, trabalhando com a situação crucial dos colonizados de terem que se exprimir na língua do outro (colonizador), volta a refletir sobre a situação do exilado que rompe com sua tradição, se desenraiza, torna-se em parte amnésico, o que desencadeia "a pulsão genealógica, o desejo do idioma, o movimento compulsivo em direção à anamnese, o amor destrutivo pelo proibido" (1996, p. 116).

Na mesma obra, J. Derrida refere ainda que podem ocorrer três situações aos que - no exílio - perdem a memória depositada na língua de origem: 1. amnésia total (uma espécie de loucura); 2. adesão homogêna à língua dominante (outra espécie de loucura); 3. hipermnésia, ou suplemento de fidelidade, excrescência da memória. É nesse sentido que ele volta a falar de traces, de escritura, de língua, de experiências "que levam para além da simples reconstituição de uma herança dada, para além de um passado disponível" (p.116-117).

Trace corresponde a marcas deixadas pela passagem de um ser ou objeto, pista, resto, vestígio. Segundo J. Derrida "não existe presente que não seja constituído sem referência a um outro tempo, a um outro presente" (Apud, Wolfreys, 2007, p.19). Wolfreys, em Compreender Derrida, relembra as teses do filósofo francófono, que via a literatura "como o receptáculo dos resíduos e traduções daqueles discursos e práticas do passado que deixam suas marcas de fantasma em nós mesmos, no que chamamos nosso presente, na identidade de hoje ou onde alguém está, na (essa coisa estranha chamada) literatura" (p. 210). Nessa medida, toda escritura é uma casa assombrada, devido a intercorrências tais como citações, alusões, menções, recordações, referências, etc. 


\section{Conexão Letras}

Paul Ricoeur também faz alusão, ao estudar a memória, à marca deixada por um timbre em cima de cera quente: "se a marca é presente, o timbre já não o é". Usa esta metáfora para falar de imagens (lembranças) que se apresentam como trace (vestígios, marcas), signos da coisa ausente (Ricoeur, 2003, p.16). Nessa mesma linha, Édouard Glissant retoma a metáfora da trace, valorizando-a no sentido de afirmar que "la pensée de la trace est celle qui s'oppose aujourd'hui le plus valablement à la fausse universalité des pensées de système" (Glissant, 1995, p. 15). Utiliza esta imagem quando descreve o migrante nu (escravo) trazido à força da África e obrigado a aderir à cultura dos senhores, colocando a questão: o que vai se passar com este migrante? "Il recompose par traces une langue et des arts qu' on pourrait dire valable pour tous". O exemplo que o autor apresenta é o seguinte: a conservação por determinadas comunidades que chegaram ao Novo Mundo de tradições, cantos, lendas, cerimônias de enterro, festas, etc. não foi possível para o deportado africano, que chegou em condições muito precárias e na condição de propriedade do senhor branco. Contudo, ele fez algo de imprevisível a partir unicamente do poder da memória: a partir dos vestígios que lhe restaram pôde (re)compor, de um lado, línguas crioulas com base em vestígios das línguas africanas e, de outro, formas de arte como o jazz, reconstituído nas Américas a partir de traces de ritmos africanos, sendo hoje considerado música de todos e não apenas da comunidade afro-americana (cf. Glissant, 1995, p.15).

Parte-se então desses conceitos para proceder à leitura de Breviário das terras do Brasil, procurando avaliar as estratégias do autor ao resgatar fragmentos de memória coletiva, que restaram do processo avassalador da colonização, e recompor elementos de nossa história que os documentos oficiais foram incapazes de "reter".

\section{Breviário das terras do Brasil: uma aventura nos tempos da Inquisição}

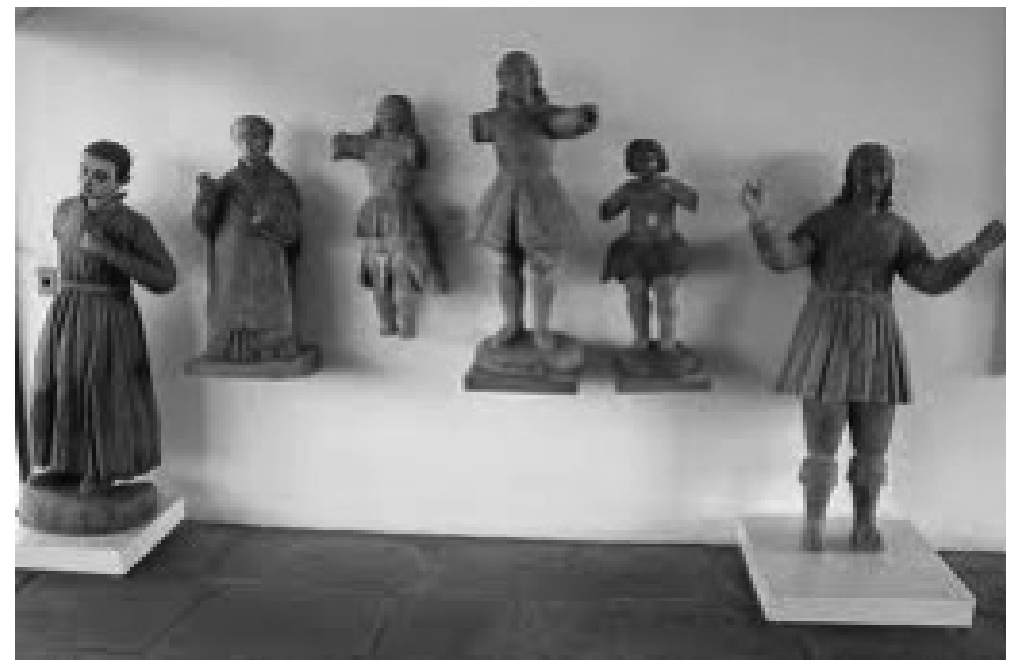

Figura 1 - Estatuária missioneira

O leitura do Breviário das terras do Brasil, nos faz recuar ao Brasil do século XVIII e mergulhar na pouco conhecida história da presença dos inquisidores em nosso país. Muito 
pouco desses sombrios acontecimentos foram retidos por nossa melhor historiografia. Verifica-se nessa ficção de Luiz Antonio de Assis Brasil, editado pela L\&PM em 1997 e publicado inicialmente como folhetim no Diário do Sul de julho a setembro de 1988, um verdadeiro trabalho de reconstituição de um período da História do Brasil a partir de vestígios, de marcas deixadas pelos guaranis que, ao reproduzirem o Barroco europeu em suas esculturas, subvertiam o modelo proposto, acrescentando marcas de sua própria cultura.

A obra inicia com a utilização de uma belíssima metáfora: a escultura, representando um Cristo, feita pelo índio guarani Francisco Abiaru, naufraga junto com seu autor, ficando ambos à deriva depois do naufrágio do barco em que se encontravam durante uma tentativa mal-sucedida de descer o Rio da Prata para chegar das Missões Jesuíticas à cidade de Buenos Aires. Trata-se de uma alusão ao desaparecimento quase total da chamada arte missioneira, desenvolvida no âmbito do processo de evangelização dos guaranis realizado pelos jesuítas espanhóis em território onde hoje se situam as fronteiras do Brasil, do Uruguai e da Argentina. Os padres, em sua missão evangelizadora, tentavam aproximar os índios da cultura europeia, propondo-lhes modelos musicais e escultóricos vigentes na Europa nos séculos XVII e XVIII.

O pretendido processo de aculturação encontrou resistência por parte dos guaranis que, ao reproduzirem o modelo do barroco europeu, o transgrediam, representando as figuras dos santos e até do próprio Cristo, com a pele amorenada, os olhos amendoados e usando, por vezes, cocares e outros adereços típicos, como penas de aves, da cultura indígena. Estavam iniciando com tais procedimentos, já no início do século XVIII, as estratégias de apropriação e devoração da cultura europeia, tal como será preconizado dois séculos mais tarde pelos modernistas, na Semana de Arte Moderna e, posteriormente, pelo Manifesto Antropófado de 1928.

Do choque das duas culturas começava a ser gestada uma nova, a cultura americana, oriunda de fecundos processos de transculturação durante os quais, do contato de duas culturas, ocorre a perda de elementos da cultura de origem e a passagem de elementos culturais de um modelo a outro, dando origem a produtos culturais novos, e necessariamente mestiços. O grande feito do autor foi o de flagrar, no início do século XVIII, em pleno Brasil colonial, através de uma escultura salva de um naufrágio, a prova do processo de transculturação que esteve na gênese da cultura brasileira e latino-americana.

Como em vários de seus romances, escritos posteriormente, como $O$ pintor de retratos e Música perdida, Assis Brasil focaliza o tema do embate travado entre a cultura ocidental eurocêntrica, que quer impor-se não apenas como superior mas como única possível, e a cultura autóctone americana que, na impossibilidade de deter o curso avassalador da colonização, sabota o processo de aculturação, apropriando-se dos "modelos", imprimindo neles as marcas de sua cultura e preservando, assim, os traços de sua própria identidade.

Por que o livro se autonomeia um "breviário"? Como sabemos, breviário é um livro que contém de forma prática e abreviada todos os textos necessários para o ofício divino, condensando, em um só volume, o que se encontra disperso em vários livros. Trata-se, portanto, de uma reflexão condensada sobre as terras do Brasil nos tempos da Inquisição. Condensada, porém, essencial para a compreensão de nossa formação cultural e, por extensão, da construção de nosso identitário mestiço. A obra revela como se engendra e se hibridiza a cultura nacional, como os tentáculos do eurocentrismo 
pretendiam se impor sobre as culturas autóctones e como as estratégias de desvio e de mobilidade conseguiram driblar o monologismo oficial. Fica sutilmente manifesto que o barroco passa, em terras americanas por uma reciclagem e constrói-se como crítica ao projeto iluminista eurocêntrico.

O Breviário constrói-se, pois, a partir da imagem do Salvador, destroço de um naufrágio e ao mesmo tempo tábua de salvação para o índio que só consegue salvar-se por ter-se agarrado fortemente à imagem de madeira. Para ele, tão importante quanto salvar sua vida era salvar sua obra de arte: um Cristo de olhos amendoados como o dos guaranis o qual ira despertar a ira do Visitador. "Apenas lhe restava o salvador, e nunca Ele foi tão merecedor deste nome" (1987, p. 10). Os olhos amendoados da escultura guarani revertem o conceito de que o homem foi criado à imagem e semelhança do criador. Aqui Deus é recriado à imagem e semelhança dos indígenas da nação guarani, remetendo ao fato de que Cristo "pode ter os rostos de todas as nações" (p. 91) já que veio à terra para redimir a humanidade. O procedimento, contudo, foi considerado pelo tribunal da Inquisição como uma "heresia implícita", crime que poderia ser punido com a pena capital, já que subvertia o cânone até então aceito por todos os escultores na Europa e nas colônias.

A ficção retém, assim, o início do que viria a ser um longo processo de hibridação cultural nas Américas, a começar pelo nome do personagem que tem o prenome cristão Francisco - e o sobrenome guarani - Abiaru. Sua obra, exemplar da estatuária missioneira, será plasmada a partir da combinação de elementos das duas culturas, apontando para a impossibilidade de o artista americano imitar servilmente os modelos estrangeiros. A repetição pura e simples não existe: o "modelo" reproduzido em outras geografias e latitudes nunca será totalmente fiel, até mesmo pela utilização de materiais e anilinas locais, inexistentes no contexto europeu. No Novo Mundo o barroco assumirá feição original, desvelando a cara miscigenada de seus artífices.

A Inquisição, contudo, outorgando a si própria o direito de legislar sobre os destinos dos povos colonizados, não chega a compreender a originalidade do que está sendo produzido, vendo as obras do artista guarani como aberração, como monstruosidade, "como produto de uma mente ociosa e inculta" (p. 156).

Vale lembrar aqui a etimologia de "híbrido (hybris)" que remete à ultraje, à ultrapassagem de limites, algo que merece punição por desrespeito às normas estabelecidas. Assim, os acusadores de Abiaru o julgam merecedor da pena de morte pela heresia de ousar desobedecer as regras da tradição europeia no que diz respeito à arte religiosa, construindo uma obra híbrida, ficando evidentes os elementos culturais de sua própria etnia. Deste modo conclui o acusador de Abiaru: "As peças que obrou durante o tempo em que esteve na oficina de Mestre Domingos bem atestam sua índole malévola e pervertida" (p. 213). De modo surpreendente, o Visitador, que preside o tribunal composto na cidade do Rio de Janeiro para julgar vários "infratores", conclui pela absolvição de Abiaru. Esse, contudo, convicto que estava de sua condenação, salta na máquina voadora junto com um holandês, também acusado de heresia e condenado a utilizar a máquina que ele afirmava servir para voar.

\section{Concluindo}

O final é ambíguo já que o leitor não fica sabendo se o aparato voador conseguirá chegar à planície com seus tripulantes a salvo. Deixar o final em aberto, constitui-se em estratégia do autor que pode ser lida como uma impossibilidade de prever o futuro 
dessa aventura artística e cultural que se encena em terras do Novo Mundo. O fator de imprevisibilidade acerca do devir da cultura em terras americanas fica assinalado através da tática de deixar a obra aberta.

Assis Brasil não reescreve a História do Brasil do início do século XVIII; ele reinventa um tempo perdido pelas omissões da História, um "tempo amnésico", como refere Pierre Ouellet, na medida em que a obra se constrói num espaço-tempo intervalar que se situa entre memória e esquecimento. Somente a ficção pode reconstruir a partir de rastros - as marcas que os guaranis deixaram no barroco missioneiro - os fatos relegados ao esquecimento como os primeiros sinais de insubmissão aos moldes europeus e os primeiros passos do processo ainda inacabado de transculturação. Tal procedimento revela a proposta do autor de dotar o Brasil de uma memória longa, colocando como ator principal um índio guarani que ousou modificar o cânone artístico de seu tempo.

O Brasil e seus primeiros habitantes — os índios — passam a constituir essa memória longa, em um plano de superioridade artística em relação aos portugueses. Cabe ao índio guarani, secundado por uma prisioneira negra, a rainha Hécuba, o papel de deslocar e inserir elementos de suas memórias coletivas nos procedimentos de transferência cultural que têm lugar com a chegada dos europeus e dos escravos ao Brasil, a partir do século XVI. Surge desse modo uma cultura brasileira como "receptáculo de resíduos e tradução de práticas do passado", para retomarmos a definição de trace proposta por J. Wolfreys, com base nos ensinamentos de J. Derrida.

\section{Referências}

ASSIS BRASIL, L. A. Breviário das terras do Brasil. Porto Alegre: LP\&M, 1992. BAHIA, Márcio; MOSER, Walter; PEREIRA, Maria Antonieta (orgs). Filmes de (an) amnésia: memória e esquecimento no cinema comercial contemporâneo. Belo Horizonte: FALE/UFMG/A tela e o texto, 2009.

BERND, Zilá (org.). Dicionário das mobilidades culturais: percursos americanos. Porto Alegre: Literalis, 2010.

BOUCHARD, Gérard. Jogos e nós de memória: a invenção da memória longa nas nações do novo mundo. Trad. de Z. Bernd. In: LOPES, C.G. et alii (orgs). Memória e cultura: perspectivas transdisciplinares. Canoas: Salles/Unilasalle, 2009. p. 9-38. DERRIDA, Jacques. Gramatologia. São Paulo: Perspectiva, 2008. Estudos 16. .Le monolinguisme de l'autre. Paris: Galillé, 1996.

GINZBURG, Carlo. O fio e os rastros; verdadeiro, falso, fictício. São Paulo: Cia das Letras, 2007.

GLISSANT, Édouard. Introduction à une Poétique du Divers. Montreal: Presses de l'Université de Montreal, 1995.

OUELLET, Pierre. La vie de mémoire. Montreal: Le Noiroit, 2002.

. Hors-temps; poétique de la posthistoire. Montreal: VLB, 2008. (Collection Le soi et l'autre).

RICOEUR, Paul. A memória, a história, o esquecimento. Campinas: Unicamp, 2007. Trad. de Alain François et alii.

SELIGMANN-SILVA, Márcio (org.) Palavra e imagem; memória e escrita. Chapecó: Argos, 2006.

WOLFREYS, Julian. Compreender Derrida. Rio de Janeiro; Vozes, 2007. 